\title{
Approaches for the Development of Rapid Serological Assays for Surveillance and Diagnosis of Infections Caused by Zoonotic Flaviviruses of the Japanese Encephalitis Virus Serocomplex
}

\author{
Jody Hobson-Peters \\ Australian Infectious Diseases Research Centre, School of Chemistry and Molecular Biosciences, The University of Queensland, \\ St Lucia, QLD 4072, Australia \\ Correspondence should be addressed to Jody Hobson-Peters, j.peters2@uq.edu.au
}

Received 1 November 2011; Revised 24 January 2012; Accepted 29 January 2012

Academic Editor: Stuart D. Blacksell

Copyright () 2012 Jody Hobson-Peters. This is an open access article distributed under the Creative Commons Attribution License, which permits unrestricted use, distribution, and reproduction in any medium, provided the original work is properly cited.

Flaviviruses are responsible for a number of important mosquito-borne diseases of man and animals globally. The short vireamic period in infected hosts means that serological assays are often the diagnostic method of choice. This paper will focus on the traditional methods to diagnose flaviviral infections as well as describing the modern rapid platforms and approaches for diagnostic antigen preparation.

\section{Introduction}

Flaviviruses are responsible for a number of important mosquito-borne diseases of man and animals globally. The Flavivirus genus, consists of 50 species and 23 viral subtypes [1], which are further separated into 12 groups based on phylogenetic analysis of the NS5 gene [2], as well as antigenic and ecological similarities [1]. Members of the globally distributed Japanese encephalitis serocomplex, include viruses such as West Nile virus (WNV), Murray Valley encephalitis virus (MVEV), St. Louis encephalitis virus (SLEV), and Japanese encephalitis virus (JEV) [1]. Other serocomplexes include yellow fever virus (YFV), tick-borne encephalitis virus (TBEV), and Dengue virus (DENV) $[3,4]$. Of recent concern is the rapid spread of a particularly virulent strain of WNV through North, Central, and South America [5]. This mosquito-borne virus can cause a fatal form of encephalitis in humans, birds, and horses [6,7] and since its introduction to America in 1999, it has caused tens of thousands of clinical cases and thousands of deaths in humans and horses $[8,9]$. More recently, a WNV outbreak occurred in Europe during 2010 and 2011, where it has been reported that there were 197 humans cases of neuroinvasive disease caused by WNV in 2010 and a further 31 cases between July and August 2011 $[10,11]$. In 2011 there was also an outbreak of encephalitis in horses caused by the WNV subtype, Kunjin virus (KUNV), in the south-eastern areas of Australia [12].

The viruses of the JEV serocomplex are maintained in nature in a cycle involving mosquitoes and in most cases, birds as the vertebrate host. However, pigs usually serve as an amplifying host during outbreaks of JEV. While horses and humans can become infected, they are classified as "dead-end hosts" as the viraemia is usually insufficient to subsequently infect feeding mosquitoes [13]. Similarly, this low level of viraemia, particularly at the time of clinical presentation for both humans and horses limits the likelihood of detecting viral antigen or RNA. Thus, diagnosis of flaviviral infections is commonly achieved using serological assays such as plaque reduction neutralization tests (which are time consuming and require the handling of live virus) and ELISA. While assays such as ELISA are ideal for high-throughput screening, they are not readily adaptable to rapid, pen-side testing. The cross-reactive nature of the immune response to flaviviral infections also causes problems for the specific diagnosis of flaviviral infections and the development of rapid immunoassays [14].

There have been numerous approaches to improve the specificity of serological-based flavivirus diagnostic assays. These include preparing sub-unit antigens, identifying immunogenic peptides and competitive blocking assays. 
Although this review will focus predominantly on the approaches used to improve diagnostic assays for WNV, these approaches are applicable to the other viruses of the JEV serocomplex, since they have similar ecology, epidemiology and pathology.

\section{Considerations for the Development of Flavivirus Diagnostic Assays}

2.1. Viraemia and Antibody Development during Flavivirus Infection. In humans, clinical symptoms of WNV disease, such as a mild febrile illness with fever, headache, and fatigue [15], generally appear two to 14 days postinfection [1618]. However, in some infections acquired through blood transfusion, symptoms were not observed for up to 22 days [18]. After a laboratory-acquired infection of the Australian WNV subtype, KUNV, the infected individual developed symptoms 9 days after the presumed infection date [19]. Less than $1 \%$ of WNV infections result in neurological disease, which can be fatal [20-23]. Although viraemia can be present at symptom onset during flaviviral infections, the delay in most patients presenting to a medical practitioner $[22,24]$ means that detection of blood-borne virus or viral RNA can be difficult. While the exact time from the bite of a WNV-infected mosquito to detectable levels of circulating viral RNA in the patient's blood is not known [25], an early study involving the inoculation of terminally ill cancer patients with Egyptian strains of WNV, indicated that virus could be detected in the blood one to two days postinfection [26]. Following the laboaratory-acquired infection of the individual with KUNV, the virus was isolated 8-10 days postinfection [19]. Screening of viraemic blood donors in the USA by Busch et al. (2008), revealed persistence of viral RNA for about 19 days, as determined by nucleic acid amplification testing [25]. In this study, IgM seroconversion occurred at about four days after the detection of RNA. However, in two laboratory-acquired infections, IgM was not detected until 13-17 days postinfection [16]. Interestingly, in one study, anti-WNV IgM was shown to persist for an average of 156 days [25] and was present for well over a year [27], rendering IgM serological assays unable to differentiate past and recent infections. IgG seroconversion occurs one to four days after the appearance of $\operatorname{IgM}[25,28]$. In a study exploring the IgM and IgG responses to JEV infection, similar kinetics to those reported for WNV were observed [29]. In this study, of the 32 patients that were admitted to hospital with acute encephalitis, 53\% of the JEV seropositive patients had IgM present at admission, and all had IgM by 7 days postadmission. By day $180,39 \%$ of the patients still had detectable IgM. The IgG response peaked 30 days after admission and was still detectable in half of the cases after 180 days.

WNV infection of horses in the USA has had a significant effect on the equine industry [30]. Approximately $10 \%$ of infected horses show signs of disease [13]. The symptoms are generally neurological and include ataxia, paralysis, and altered behaviour [31]. Experimental infections have induced a virus neutralising immune response by seven to
12 days postinfection $[13,32,33]$ and clear IgM seroconversion around day seven postinfection [13]. The detection of virus in the blood of the experimentally infected horses in the study by Bunning et al. (2002) [13] occurred from days 1 to 3 postinfection and persisted until day 5 or 6 for all of the horses, except for one which only had detectable viraemia on days 3 and 4 . Only one of the horses developed clinical signs of disease, which occurred on day 8 postinfection, and thus outside the window for virus detection, highlighting the requirement for antibody-based diagnostic assays for horses as well. Infection of horses with KUNV or MVEV can also cause a neurological disease [12, 34-36], although experimental infection of a limited number of horses with MVEV failed to induce clinical symptoms [37]. In this study, five of the 11 experimentally infected animals had detectable levels of the virus in their blood from day 1 to day 5 postinfection. All of the horses developed an antibody response to MVEV seven to fourteen days postinfection.

\subsection{Geographical Distribution of the Pathogenic Flaviviruses and Considerations for Serological Diagnostic Assay Specificity.} The presence of flaviviruses of the JEV serocomplex within the same geographic regions poses problems for the diagnostic specificity of serological assays due to the development of cross-reactive antibodies during flaviviral infections [4]. In North America, the presence of WNV and SLEV complicates serological specificity when diagnosing infections in humans and horses [38, 39]. In South America, in addition to WNV and SLEV, flaviviruses that should also be considered when testing equine sera include Ilheus virus and Bussuquara virus, although recent serosurveys have not found any equines with Bussuquara virus-neutralising antibodies [4042]. In Europe, the African flavivirus, Usutu virus, was detected for the first time in sentinel horses, chickens, and birds during surveillance for WNV in 2008 and 2009 [43] and has since caused neurological disorders in patients in Italy $[44,45]$. WNV caused a major outbreak of encephalitis in Greece in 2010 and cross-reactivity between WNV and DENV was observed when testing patient sera from this outbreak [46].

Australia has the largest number of different JEV serogroup species in the world. There have been incursions of JEV in the northern areas of the continent, while in recent years there have been outbreaks of dengue virus in northern Queensland. Kunjin virus is endemic in Northern Australia and in 2011 there was an outbreak of equine encephalitis with a $10-15 \%$ case fatality rate, caused by a virulent KUNV strain in South Eastern Australia [12]. In addition to KUNV and JEV, humans and horses also develop infections to MVEV and Kokoberra, which can also complicate serological diagnosis [34-37] (May et al., manuscript under revision). Indeed, sequential exposure to different flaviviruses enhances the production of flavivirus cross-reactive antibodies, leading to false positives in some serological assays [47].

Prior vaccination against one or more flaviviruses must also be considered when interpreting assay specificity. $\mathrm{Hu}-$ man vaccines are available for tick-borne encephalitis virus, JEV and YFV and a recent study showed cross-neutralisation 
of DENV, WNV, and/or louping ill virus (LIV, which is a member of the TBEV serocomplex) by human serum samples taken following vaccination against TBEV and JEV [48]. The likelihood of samples cross-neutralising DENV and WNV was increased if the individuals were also vaccinated against YFV, in addition to JEV and TBEV. False positives in WNV assays have also been documented when assessing serum from JEV-vaccinated horses [49].

2.3. The Immunogenic Flavivirus Proteins. The flavivirus virion is spherical, enveloped, and approximately $500 \AA$ in diameter [50]. It consists of a host-derived lipid bilayer containing 180 copies of the envelope (E) and membrane (M) proteins, which are arranged in a herringbone pattern [50, 51]. This envelope surrounds a nucleocapsid core which contains the single stranded, positive sense RNA genome of approximately $11 \mathrm{~kb}[52,53]$. The genome contains a single open reading frame (ORF), bounded by $5^{\prime}$ and $3^{\prime}$ untranslated regions [54]. The ORF is translated as a single polyprotein of three structural and seven nonstructural proteins, which are cleaved by viral and cellular proteases [55].

The immunodominant antigens during WNV infection are the E, prM, and NS1 proteins [56-62], although antibodies to the nonstructural proteins NS3 and NS5 have also been detected in humans $[63,64]$.

2.3.1. The Envelope Protein. The E protein is the dominant protein present on the surface of the flavivirus virion $[50,51]$. It is a major target for neutralising antibodies [65-67]. The E protein monomer is divided into three domains. Domain I (DI) features an eight-stranded $\beta$ barrel $[51,68,69]$ and in many of the recent virulent WNV strains isolated, it contains the sole E protein N-linked glycan moiety [53]. Domain II (DII) contains the highly conserved fusion peptide [70] and Domain III (DIII) is an immunoglobulin-like structure [71] which is likely to participate in receptor binding $[68,72]$.

WNV E protein neutralising epitopes have been welldefined and map to all three domains [71, 73-75]. The majority of potent neutralising monoclonal antibodies ( $\mathrm{mAb}$ ) bind DIII, in particular residues 302-309 and 330-333 of the lateral ridge [71, 75-77]. Importantly, these epitopes are more likely to be type specific, but are not the target of most antibodies generated during WNV infection of humans and horses [59, 74]. Recent studies have revealed that most antibodies are directed to DII epitopes [59], which tend to be highly cross-reactive $[78,79]$.

2.3.2. $\mathrm{prM} / \mathrm{M}$. $\mathrm{prM}$ is a $20-25 \mathrm{kDa}$ precursor to $\mathrm{M}$ protein and is present on immature, noninfectious particles $[80,81]$ and to a lesser extent on secreted infectious particles $[82,83]$. During the virus maturation process, cleavage of prM by the cellular protease, furin, at a highly conserved cleavage site [84], results in the release of the singly glycosylated pr protein [84-86]. Furin cleavage of prM occurs only after exposure of the protein to low $\mathrm{pH}$ in the late endosomes [84].

While the crystal structure for WNV prM has not yet been determined, DENV prM was recently crystalised and the structure elucidated [87]. This study revealed that the pr protein consisted of seven beta strands and confirmed that the protein structure was stabilised by the presence of three disulphide bonds. The pr peptide covers the E protein fusion peptide loop (DII) in the immature virus, thus pre-venting premature fusion of the virus particle with the host cell membrane during transport through the trans-Golgi network $[80,88]$.

Antibodies to prM are generated during flaviviral infection $[59,62,89]$. Western blot analysis using whole viral antigen and WNV-immune horse serum clearly demonstrates that the majority of antibodies generated during WNV infection are directed to the $\mathrm{E}$ and prM proteins [62]. Generally, the anti-prM antibodies do not elicit potent virus neutralisation in vitro. However, they can be protective in vivo [90-93]. A study by Cardosa et al. (2002) suggested that antibodies to prM may be virus specific, due to the ability of this antigen to differentiate DENV and JEV infections in humans [89]. However, in another study, immune serum from SLEV- and WNV-infected humans showed crossreactivity between WNV and SLEV prM [94]. Nevertheless, prM may be a potential candidate antigen for incorporation into species-specific assays.

2.3.3. NS1. NS1 is a glycosylated, nonstructural protein, of about $48 \mathrm{kDa}$ which has a highly conserved structure that is stabilised by six disulfide bridges $[95,96]$. To date, there has been no success in crystallising NS1. However, electron microscopy has recently provided some insight into the structure of the hexameric secreted form of NS1 [97, 98]. NS1 is thought to have an important role in RNA replication [99-102] and has been colocalised with the double-stranded RNA replicative form [100]. NS1 also appears to have a role in immune evasion, as it has been shown to attenuate complement activation [103]. While a large amount of NS1 remains in the infected cell [104], it is also actively secreted at relatively high levels [104-107]. This secreted protein stimulates a strong [108-110], protective, but non-neutralising antibody response [111-113] and it has been targeted by serological assays $[56,58,114-116]$. There have also been numerous mAbs generated to this protein $[111,117-120]$, some of which have been incorporated into antigen capture assays for the early detection of virus infection $[104,121]$.

\section{Serological Diagnosis of Flaviviral Infections}

\subsection{Traditional Approaches}

3.1.1. Plaque Reduction Neutralisation Tests. The Plaque Reduction Neutralisation Test (PRNT) is the gold standard for the serological diagnosis of flaviviral infections. PRNT and virus neutralisation tests (VNT) assess for serum antibodies that bind to the viral envelope protein and prevent virus entry into the cell (normally Vero cells for flavivirus assessment) in vitro $[122,123]$. In PRNT, neutralisation of the virus by antibodies in the infected patient's serum is evidenced by a reduction of plaques relative to the serum dilution. Virus neutralisation in VNTs results in the absence, 
or, decrease in visible cytopathic effect in the cell monolayer. PRNT can be highly specific, although the accuracy of interpretation of the results depends upon simultaneous assessment against flaviviruses endemic to a given area, to allow for comparison of end-point titres. Other disadvantages of these tests are that they are labour intensive, require skilled personnel, a minimum of five days to perform, and the handling of live virus, which requires a BSL-3 (Biosafety level 3) facility (Table 1).

3.1.2. Haemagglutination Inhibition Assay. Haemagglutination and Haemagglutination Inhibition assays (HI) have been widely used for the detection of arthropod-borne viruses and the antibodies developed to these viruses, respectively $[14,124]$. These assays exploit the ability of the envelope glycoprotein to bind and agglutinate avian erythrocytes so that they form a visible lattice in a U-bottom microtitre plate. In the $\mathrm{HI}$ assay, antibodies from infected individuals prevent the agglutination of the erythrocytes, which subsequently form a pellet. While the HI assay was used extensively in the past for flavivirus serology, this technique has now been largely superseded, in favour of assays with better sensitivity and specificity, but is still used in some instances for surveillance $[125,126]$. The advantages of $\mathrm{HI}$ assays are that providing avian red blood cells are available, the assays can be performed with minimal training and equipment and the antigen used can be inactivated by a simple extraction process. However, as for PRNT, there is a requirement for the simultaneous assessment for flaviviruses endemic for the area and multiple different $\mathrm{pH}$ buffers are required for each different antigen. A constant supply of fresh avian red blood cells is also necessary and there is a high level of cross-reactivity amongst the flaviviruses [127].

3.1.3. Immunofluorescence Assay. The Immunofluorescence assay (IFA) can be used to differentiate the IgM and IgG responses to flaviviral infection. It involves incubating patient serum with glass slides, upon which are fixed flavivirus-infected cells. The patient's virus-specific antibodies are then detected with a fluorophore-conjugated antispecies IgM or IgG immunoglobulin. The benefit of this assay is that prefixed slides can be stored at $4^{\circ} \mathrm{C}$ and a BSL-3 facility is not required to perform the assay and results can be obtained quickly, particularly due to the commercialisation of IFA kits (e.g., Focus Diagnostics Arbovirus IFA). However, crossreactivity of immune antibodies with closely related flaviviruses can impair the accuracy of the diagnosis and there is a requirement for a fluorescent microscope to evaluate the results.

3.1.4. ELISA. ELISA is routinely used for the diagnosis of WNV infection [140]. IgG- and IgM-capture (MAC-ELISA) ELISAs for WNV were originally developed by the Centers for Disease Control (CDC) and applied to human and equine WNV infection diagnosis [32, 141-143]. Prior to this, IgG and IgM capture ELISAs were developed in the 1980s for the detection of antibodies to JEV [29]. The MAC-ELISA was developed to diagnose recent infections and involves the capturing of test-serum IgM with immobilised antispecies IgM, followed by the addition of WNV antigen and detection with a flavivirus-specific, horseradish peroxidaseconjugated monoclonal antibody. The first Food and Drug Administration- (FDA-) cleared assay of this nature was developed by PanBio, who have since released improved versions with increased accuracy [144]. The persistence of IgM from WNV infections $[25,27,28]$ led to the development of avidity testing, in order to improve the usability of ELISA for differentiating past and recent infections [145]. Specificity problems associated with flavivirus cross-reactivity, have been reduced through the application of algorithms [146]. The sensitivity and specificity of commercially available ELISAs has been reviewed by Zhang et al. (2009) [147]. A survey of public health and commercial diagnostic reference laboratories in 2008 revealed that ELISA or microsphere immunoassay-based IgM and IgG assays were most commonly used for the diagnosis of WNV infections, with significantly fewer laboratories using PCR, PRNT, and culture isolation [148].

Defined epitope blocking ELISAs have also been used to increase the specificity of WNV serodiagnosis and have been useful for differentiating flaviviral infections through targeting epitopes on NS1 [56, 58, 116] or E protein [149]. A recent study in horses has shown exquisite specificity of the blocking ELISA originally published by Hall et al. (1995) [56] when assessing serum from horses that have been sequentially infected with SLEV or DENV followed by WNV [47]. The WNV blocking ELISA was positive only when testing serum from the horses following exposure to WNV, despite previous injection with SLEV or DENV. In contrast, depending on the day, postinjection with WNV, PRNT and IgM ELISA could not always be used to accurately diagnose WNV as the most recent injected virus. Despite these data, current blocking ELISAs are unable to differentiate infections caused by different subtypes of WNV [36] and for diagnosing WNV infection in patients who have received flavivirus vaccinations or have had previous flaviviral infections [150]. Blocking ELISAs have been used extensively for surveillance for WNV in North America [41, 151-154] and for detection of KUNV and MVEV in Australia [36].

3.1.5. Immunoblot. Western blot using lysates of flavivirusinfected cell monolayers can potentially differentiate flaviviral infections $[89,94]$. In a study by Oceguera et al. (2007) [94], where serum antibody reactivity to E, NS1, and prM proteins of WNV and SLEV was analysed, NS1 was most useful in differentiating WNV and SLEV infections in humans, whereas prM was the most specific antigen for differentiating JEV and DENV virus infections in a study by Cardosa et al. (2002) [89]. Western blot using crude lysates was also used to assess for the seroprevalence of WNV in horses in sub-Saharan Africa [155]. A drawback to using Western blot to analyse sera is that frequently serum antibodies will also recognise other proteins within the cell lysates and this can make accurate interpretation of the results difficult. 


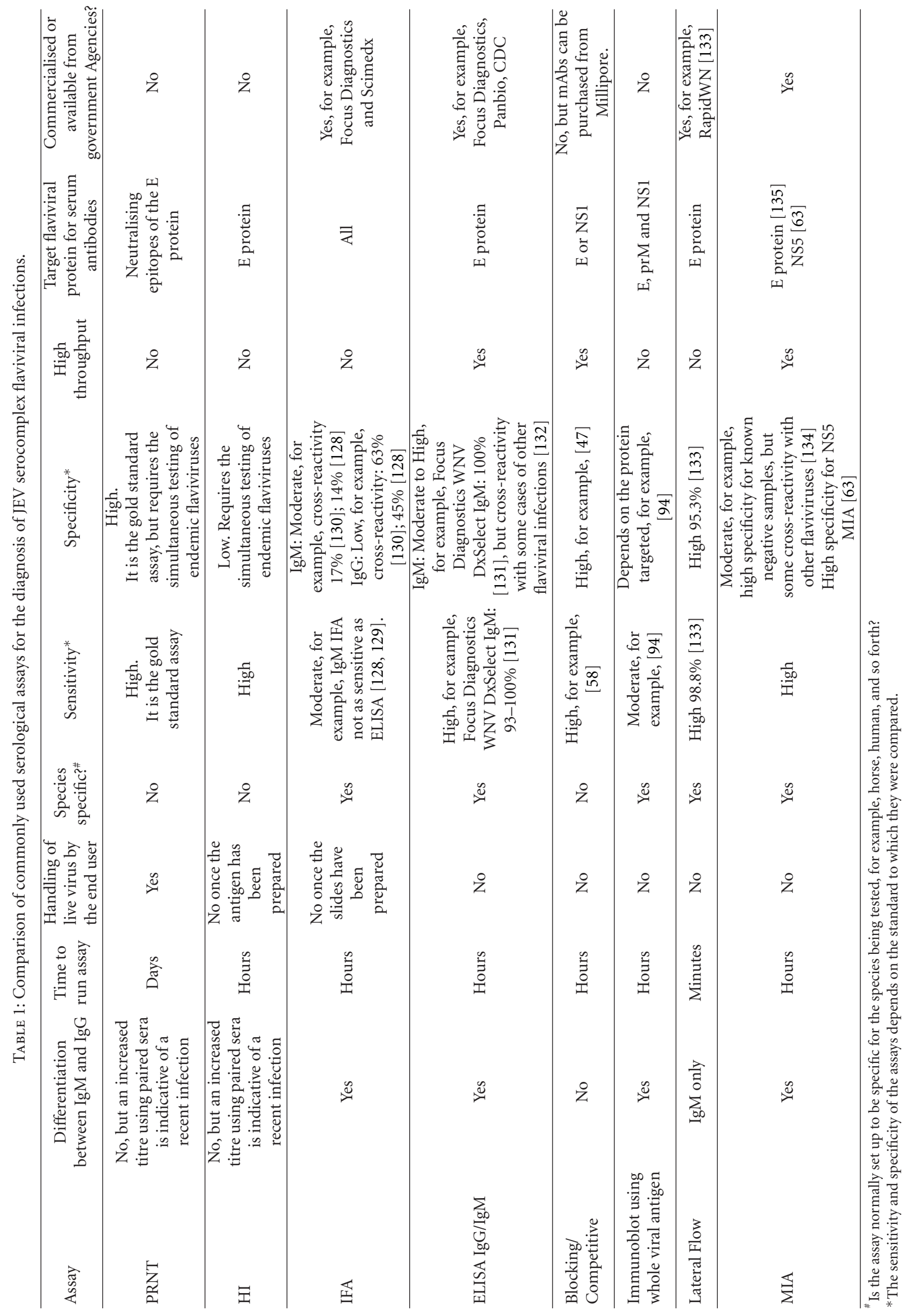




\subsection{Recent Platform and Serological Assay Developments}

3.2.1. High-Throughput, Rapid Microneutralisation Assays. An automated colorimetric microneutralization assay has recently been described for the detection of, and differentiation between, WNV and SLEV infections in humans [156]. Of the 152 PRNT-confirmed negative, WNV-positive or SLEV-positive sera, there was concordance between PRNT and the rapid microneutralisation assay for all samples except one. The advantages of this assay over traditional PRNT are that the testing duration is significantly reduced and the assay can be performed in a 96-well format, enabling 8 dilutions of each sample to be analysed simultaneously. Like PRNT, neutral red is used to stain live cells; however, in this automated assay, the stained live cells are solubilised and the optical density quantified using a plate reader. The obvious drawback to this assay is that the handling of live virus is still a necessity.

3.2.2. Lateral Flow. The FDA has recently approved a lateral flow device for the diagnosis of WNV infection in humans [133]. This assay has significant advantages over ELISA (which can take several hours to perform) in that a result is obtained within 15 minutes [157]. Lateral flow assays routinely consist of antigens or antibodies immobilised on nitrocellulose strips and utilise gold particles or coloured latex as reporter molecules. The assay is commonly housed in a plastic or cardboard cassette. In the case of the WNV lateral flow assay, anti-WNV IgM antibodies in patient serum form a tertiary complex with biotinylated anti-human IgM, recombinant WNV E protein, and an anti-E $\mathrm{mAb}$ which is coupled to colloidal gold particles. This complex is then captured by immobilised streptavidin on the nitrocellulose strip to form a pink line. This assay displayed $98.8 \%$ sensitivity and $95.3 \%$ specificity, as compared to other predicate assays [133]. However, such devices are most suitable for situations where only a small number of tests are to be performed and where qualitative results are acceptable.

3.2.3. Microsphere Immunoassay (MIA). Microsphere immunoassay (MIA) is a bead-based microfluidic system in which an antigen is attached to encoded microbeads that can be identified using a fluorescence-activated cell sorting system (FACS). Target analytes that bind the beads during the assay procedure are detected using a fluorescent molecule. MIA offers two advantages over other serological assays such as ELISA: firstly, it is possible to multiplex the assay such that one serum can be assessed for reactivity to many antigens in a single run. Secondly, MIA offers higher sensitivity through the use of fluorescence [158]. In one study using MIA, WNV NS3 and NS5 antigens were assessed for the specific detection of recent WNV infections and to differentiate those patients that had been vaccinated against flaviviral infection [63]. The NS5 MIA showed 92\% sensitivity $(n=61)$ for PRNT-confirmed WNV positive samples that were collected 7 to 77 days postsymptom onset, while none of the samples from JEV-vaccinated individuals were positive and only $5 \%$ of the samples from YFV vaccinated individuals were positive, indicating good diagnostic specificity of the assay. Further, when assessed for cross-reactivity with DENV- and SLEV-positive samples, there was $9 \%$ and $5 \%$ false positives observed, respectively, for the NS5 MIA. At the time of this study's publication, it was thought that NS5 could be used to detect antibodies from patients with recent WNV infections; however, a subsequent comprehensive study using the same platform showed that $77 \%$ of sera tested showed the presence of anti-NS5 antibodies after 90 days and 13\% of patients retained anti-NS5 antibodies after one year [64].

The MIA platform also enabled the simultaneous assessment and validation of various WNV antigens for the detection of WNV antibodies in horse sera [159] and has also been validated for the detection of anti-WNV and anti-SLEV IgM antibodies in human serum [134]. Rather than NS3 or NS5 antigen, this assay is based on the reactivity of serum antibodies to antigen captured by the anti-E monoclonal antibody, 6B6C-1 [134]. Many laboratories in the USA have adopted this assay for WNV diagnosis [134, 148]. One obvious drawback of the MIA platform is the requirement for expensive, specialised equipment.

3.2.4. Biosensors and Microfluidic Systems. The design of biosensors and microfluidic devices is targeted to field use and point of care. Some are based on dipstick and lateral flow formats, while other newer concepts use microcapillaries to direct the flow of biological samples and assay reagents through various chambers in the device. However, these are just two examples of platforms which fall into this category. In terms of advances in flaviviral research in this area, Teles (2011) provides a comprehensive critical review of biosensor-based assays for the diagnosis of Dengue infection [160]. Similarly a microfluidic system based on virus-coated magnetic beads for the detection of IgM and IgG antibodies against DENV within 30 minutes has been described by Lee et al., (2009) [161].

In terms of advances in WNV diagnosis using biosensors and microfluidic systems, a linear, 15 amino acid fragment of domain III of WNV was successfully used as an antigen on an amperometric immunosensor [162]. In a second study, a surface enhanced Raman scattering immunoassay was shown to be highly sensitive for the detection of anti-WNV immunoglobulin [163]. Using gold particles coated with WNV E protein, this assay was capable of detecting $50 \mathrm{pg} / \mathrm{mL}$ antiWNV E immunoglobulin in rabbit serum, which is 400 times more sensitive than a standard direct sandwich ELISA. However, this assay still requires validation with clinical or field sera.

3.2.5. Autologous Red Blood Cell Agglutination Assays. While not a new technology, the autologous red blood cell (RBC) agglutination assay platform has only recently been assessed in a pilot study for the detection of antibodies to WNV. This technology was patented in the early 1990's by AGEN Biomedical Ltd. and had considerable advantages over traditional haemagglutination assays, ELISA and radioimmunoassays due to its ease of use and speed in which specific and sensitive diagnosis could be made $[164,165]$. Originally 


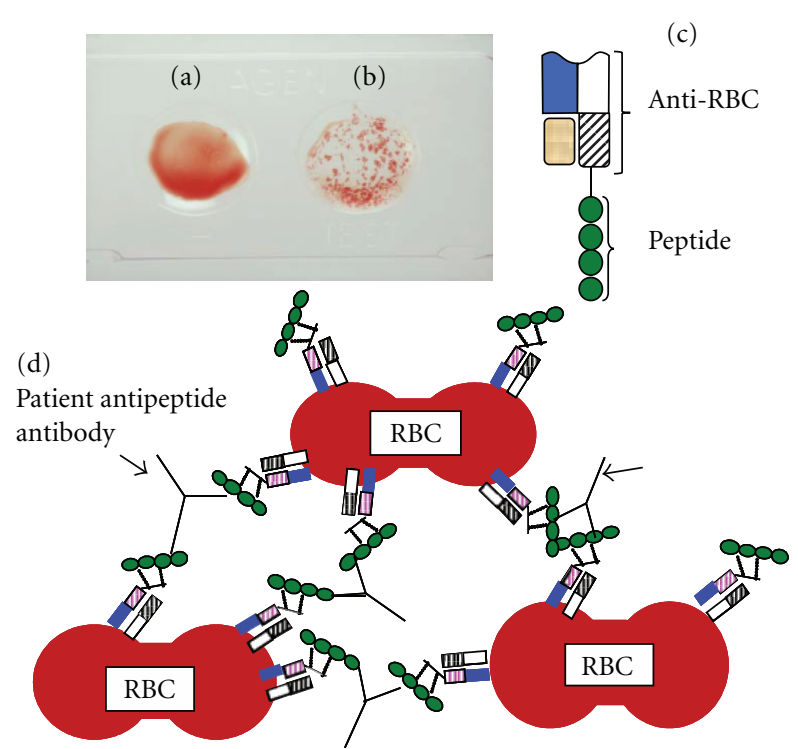

Figure 1: Autologous agglutination assay. Agglutination of RBC's (b, d) by the crosslinking of the assay reagent (c) and blood-borne antipeptide antibodies. Agglutination does not occur in nonimmune samples (a).

developed for the detection of anti-HIV antibodies in patient serum, the RBC agglutination assay reagent comprised a $\mathrm{mAb}$ with high affinity to human RBCs, chemically coupled to a specific viral antigen $[164,166,167]$. When a drop of infected patient blood was mixed with the mAb-peptide fusion protein, within two minutes, visible agglutination occured [164, 166, 167] (Figure 1).

The advantages of this agglutination assay technology are many. It is rapid, portable and minimises sample handling. Because the read-out system is the patient's own erythrocytes, there is no need for secondary reagents such as fluorophore- or gold-labelled antibodies, reagent-coated latex beads or fixed heterologous erythrocytes. Further, this assay requires minimal training, specialised equipment, electricity or running water, making it useful for emergency testing, field surveillance testing, mass screening and use in developing countries [164, 167-169]. A functional RBC agglutination assay requires the manufacture of only one component comprised of two biologicals - a peptide and an antibody fragment. In contrast, lateral-flow diagnostics require the optimisation and validation of gold-conjugation technologies and the striping of biologicals onto membranes. These processes are more technically-and time-demanding.

Several groups have explored the production of autologous RBC agglutination reagents by recombinant methods $[168,170-174]$. The feasibility of this approach was initially established in a bacterial expression system that used a single chain $\mathrm{Fv}$ fragment $(\mathrm{scFv})$ derived from the original antierythrocyte $\mathrm{mAb}$ recombinantly fused to the HIV peptide $[170,171]$. Although functional reagents were produced, the recovery of the reagent required extensive extraction and purification procedures. We recently described the secreted expression of the human-based recombinant autologous agglutination reagent in mammalian cells, as both single chain $(\mathrm{scFv})$ and intact $\mathrm{mAbs}$ [175]. The anti-RBC antibody was fused to a WNV diagnostic tag (WN19) and was shown to be functional in agglutination assays and suitable for diagnosis of WNV infection in horses. However, the reagent was not expressed at high enough levels within the cell culture medium for the true potential of this assay system to be realised. In particular, we aimed to develop a system based on generic vectors into which antigenic peptides could rapidly be incorporated and one in which the culture supernatant could be used for agglutination reactions without further processing. Recombinant expression of these agglutination reagents would enable rapid, on-demand production for minimal cost. This is particularly important for developing countries where outbreaks of new pathogens are frequent and there is a requirement for inexpensive, "point-of-care" assays.

\section{Antigen Formulations to Improve Assay Specificity}

The specificity of serological assays for the diagnosis of flaviviral infections predominantly relies on the antigen used in the assay. A number of alternative antigens to the complete E protein or total viral antigen have been assessed in recent years, particularly for improving the specificity of WNV seroassays. Some of these studies are listed in Table 2.

4.1. E Protein. The flaviviral E protein is frequently used in serological diagnostic assays [176]. However, some E protein epitopes induce flavivirus cross-reactive antibodies [66, 78] and recent attempts to improve the specificity of assays using E protein-based antigens have focused on using peptides or individual domains of the E protein [136-138]. By eliminating the cross-reactive epitopes in the E protein DII, Roberson et al. (2007) reported a WNV diagnostic antigen that conferred considerably higher specificity to diagnostic assays than its wild-type counterpart [136], reducing the number of false positives by $21-22 \%$. In a different approach, Beasley et al. (2004) developed a recombinant protein based on the E protein DIII (EDIII). When the EDIII subunit protein was used in ELISA, there was clear discrimination of WNV-immune mouse ascitic fluid from mouse immune ascitic fluids generated against JEV, MVEV, SLEV, DENV and YFV [137]. While the EDIII ELISA displayed strong correlation with HI and PRNT for the detection of antiWNV IgG in field trials with monkey, horse, and human sera, the specificity of the ELISA was not challenged with sera obtained from natural infections with other flaviviruses of the JEV serocomplex. In a more defined analysis of DIII antigens, a linear, 15-amino-acid fragment of this domain was successfully used in ELISA [138] for human WNV infection diagnosis and has also been assessed as an antigen on an amperometric immunosensor [162]. The comparative specificity of these E protein subunit antigens has not been fully investigated. However, in the ELISA, 100\% specificity and $67 \%$ sensitivity was achieved when compared with a commercial WNV IgG ELISA kit. 


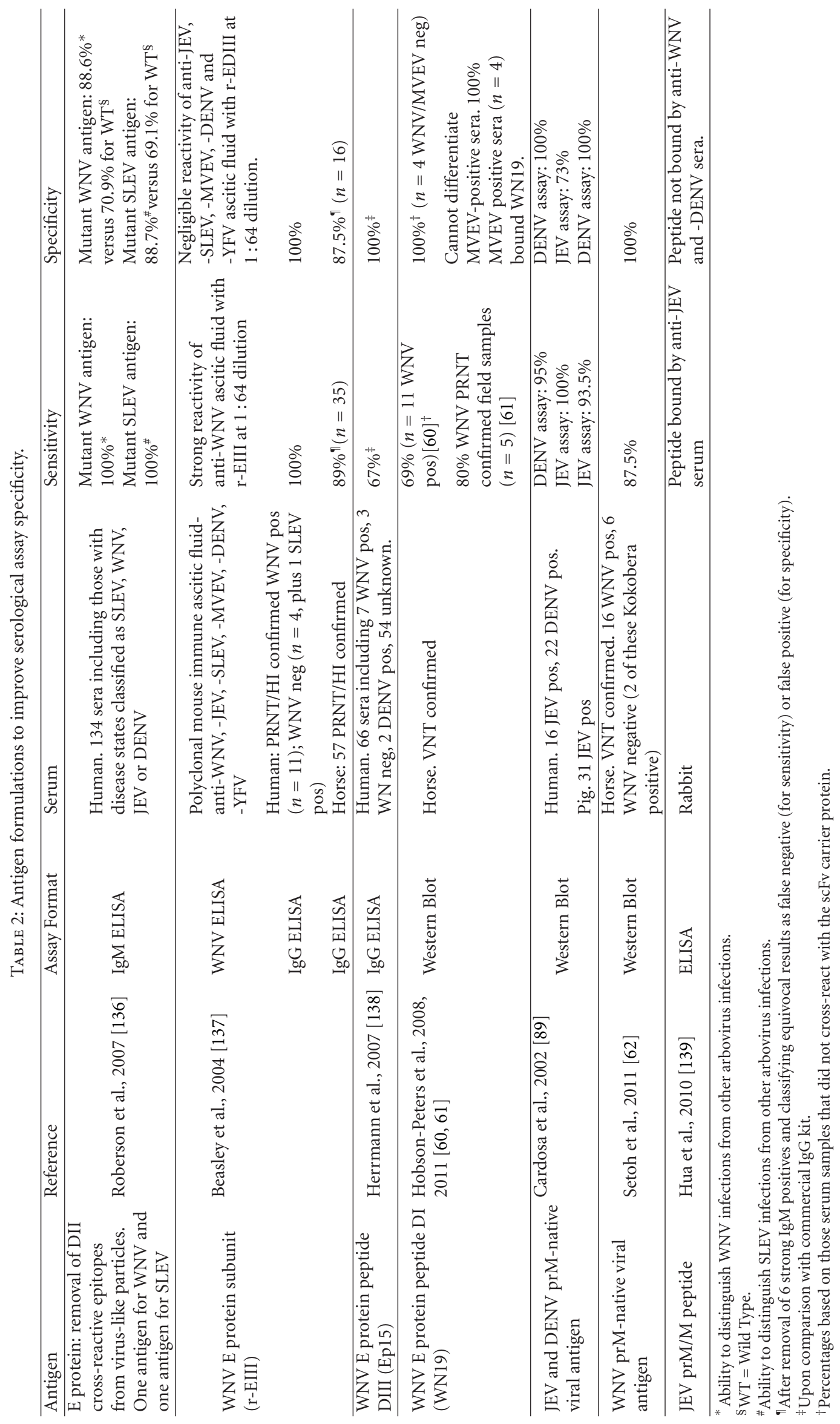


Our laboratory has identified a peptide (WN19) in Domain I of the E protein which has been successfully trialled in a small field study for the detection of anti-WNV antibodies in horse sera using Western blot $[60,61]$. The peptide WN19 sequence encompasses the WNV envelope protein glycosylation site at position 154 and it was shown that the carbohydrate moiety was required for recognition of peptide WN19 by most WNV-immune horse sera assessed. The disadvantage of compartmentalising any target antigen is that there is often a reduction in sensitivity. This is evidenced by our data where a number of samples with VNT titres $\geq 160$ reacted only weakly with peptide WN19, or not at all [60]. In Western blot, peptide WN19 was also detected by horse sera containing MVEV-neutralising antibodies.

4.2. prM. The prM antigen has been successfully used to differentiate DENV and JEV infections in humans using Western blot [89]. Western blot analysis has also shown that prM is consistently recognised by WNV-immune horse serum [62]. An obstacle to the use of the prM antigen for differentiating flaviviral infections is a difficulty in expressing a correctly folded protein. High-level expression of membrane proteins is inherently difficult and compartmentalising the prM protein so that only the soluble pr peptide is expressed, results in the elimination of the epitope(s) recognised by WNV-immune serum [62]. A detailed analysis on the use of prM to differentiate infections caused by viruses of the JEV serogroup is yet to be published.

A continuous JEV prM/M peptide that is recognised by anti-JEV rabbit serum and not by anti-WNV or -DENV serum has also been identified. However, the efficacy of this peptide in assays with clinical sera is yet to be determined [139].

\section{Conclusions}

The continued spread of flaviviruses worldwide warrants the need for rapid serological assays of increased specificity. In countries such as Australia, where multiple arboviruses infecting horses and humans can cocirculate, as well as the increased prevalence of other encephalitic-disease causing viruses such as Hendra, there is a need for the development of rapid, pen-side immunoassays. While ELISA is ideal for highthroughput testing, this assay format is not suitable for rapid point of care and veterinary pen-side testing. The development of rapid, portable flavivirus immunoassays has been impaired by the cross-reactive immune response generated against these pathogens in vertebrates. The difficulty lies in identifying a single antigen that confers both high sensitivity and specificity to the immunoassay. Multiplex assays such as MIA are ideal for giving an accurate profile of the immune response against various flaviviral antigens simultaneously. It is feasible that this platform could be used to test serum samples against NS3, NS5, E domain subunits such as DIII and the DI WN19 peptide, NS1 and prM in a single assay. However, application of flaviviral antigens to a multiplexed rapid, point-of-care device such as lateral flow has not yet been reported. Devices for multiplexed ABO blood typing agglutination assays such as the patented EldonCard system or microfluidic device [177] may be readily adaptable for use with the autologous agglutination system, particularly if larger flaviviral antigens such as E DIII or NS1 can be recombinantly fused to the RBC-binding antibody.

\section{Acknowledgments}

I would like to thank Roy Hall (The University of Queensland, Australia) and Philip Toye (ILRI, Kenya) for critical review of the paper and insightful discussions.

\section{References}

[1] F. X. Heinz, M. S. Collett, R. H. Purcell et al., "Family Flaviviridae," in Virus Taxonomy. Seventh Report of the International Committee for the Taxonomy of Viruses, M. H. V. van Regenmortel, C. M. Fauquet, D. H. L. Bishop et al., Eds., pp. 859-878, Academic Press, San Diego, Calif, USA, 2000.

[2] G. Kuno, G. J. J. Chang, K. R. Tsuchiya, N. Karabatsos, and C. B. Cropp, "Phylogeny of the genus Flavivirus," Journal of Virology, vol. 72, no. 1, pp. 73-83, 1998.

[3] J. S. Porterfield, "Arboviruses—structure and classification," Medecine Tropicale, vol. 40, no. 5, pp. 493-498, 1980.

[4] C. H. Calisher, N. Karabatsos, J. M. Dalrymple et al., "Antigenic relationships between flaviviruses as determined by cross-neutralization tests with polyclonal antisera," Journal of General Virology, vol. 70, part 1, pp. 37-43, 1989.

[5] D. J. Gubler, "The continuing spread of West Nile virus in the Western Hemisphere," Clinical Infectious Diseases, vol. 45, no. 8, pp. 1039-1046, 2007.

[6] K. M. van der Meulen, M. B. Pensaert, and H. J. Nauwynck, "West Nile virus in the vertebrate world," Archives of Virology, vol. 150, no. 4, pp. 637-657, 2005.

[7] J. J. Sejvar and A. A. Marfin, "Manifestations of West Nile neuroinvasive disease," Reviews in Medical Virology, vol. 16, no. 4, pp. 209-224, 2006.

[8] USDA, http://www.aphis.usda.gov/vs/nahss/equine/wnv/.

[9] CDC, http://www.cdc.gov/ncidod/dvbid/westnile/surv\&control.htm\#maps.

[10] K. Danis, A. Papa, G. Theocharopoulos et al., "Outbreak of West Nile virus infection in Greece, 2010," Emerging Infectious Diseases, vol. 17, no. 10, pp. 1868-1872, 2011.

[11] K. Danis, A. Papa, E. Papanikolaou et al., "Ongoing outbreak of West Nile virus infection in humans, Greece, July to August 2011," Euro Surveillance, vol. 16, no. 34, 2011.

[12] M. J. Frost, J. Zhang, J. H. Edmonds et al., "Characterization of virulent West Nile virus Kunjin strain, Australia, 2011," Emerging Infectious Diseases, vol. 18, no. 5, 2012.

[13] M. L. Bunning, R. A. Bowen, C. Bruce Cropp et al., "Experimental infection of horses with West Nile virus," Emerging Infectious Diseases, vol. 8, no. 4, pp. 380-386, 2002.

[14] G. Kuno, "Serodiagnosis of flaviviral infections and vaccinations in humans," Advances in Virus Research, vol. 61, pp. 365, 2003.

[15] J. T. Watson, P. E. Pertel, R. C. Jones et al., "Clinical characteristics and functional outcomes of West Nile fever," Annals of Internal Medicine, vol. 141, no. 5, 2004.

[16] G. Campbell and R. Lanciotti, "Laboratory-acquired West Nile virus infections-United States, 2002," MMWR, vol. 51, no. 50, pp. 1133-1135, 2002. 
[17] L. R. Petersen and A. A. Marfin, "West Nile virus: a primer for the clinician," Annals of Internal Medicine, vol. 137, no. 3, pp. 173-179, 2002.

[18] L. Shireley, K. Kruger, T. Miller et al., "Update: investigations of West Nile virus infections in recipients of organ transplantation and blood transfusion," $M M W R$, vol. 51, no. 37, pp. 833-836, 2002.

[19] B. C. Allan, R. L. Doherty, and R. H. Whitehead, "Laboratory infections with arboviruses including reports of two infections with Kunjin virus," Medical Journal of Australia, vol. 2, no. 18 , pp. 844-847, 1966.

[20] T. F. Tsai, F. Popovici, C. Cernescu, G. L. Campbell, and N. I. Nedelcu, "West Nile encephalitis epidemic in southeastern Romania," The Lancet, vol. 352, no. 9130, pp. 767-771, 1998.

[21] F. Mostashari, M. L. Bunning, P. T. Kitsutani et al., "Epidemic West Nile encephalitis, New York, 1999: results of a household-based seroepidemiological survey," The Lancet, vol. 358, no. 9278, pp. 261-264, 2001.

[22] J. J. Sejvar, M. B. Haddad, B. C. Tierney et al., "Neurologic manifestations and outcome of West Nile Virus infection," Journal of the American Medical Association, vol. 290, no. 4, pp. 511-515, 2003.

[23] D. R. O'Leary, A. A. Marfin, S. P. Montgomery et al., "The epidemic of West Nile virus in the United States, 2002," Vector-Borne and Zoonotic Diseases, vol. 4, no. 1, pp. 61-70, 2004.

[24] T. Solomon, M. H. Ooi, D. W. C. Beasley, and M. Mallewa, "West Nile encephalitis," British Medical Journal, vol. 326, no. 7394, pp. 865-869, 2003.

[25] M. P. Busch, S. H. Kleinman, L. H. Tobler et al., "Virus and antibody dynamics in acute west nile virus infection," Journal of Infectious Diseases, vol. 198, no. 7, pp. 984-993, 2008.

[26] C. M. Southam and A. E. Moore, "Induced virus infections in man by the Egypt isolates of West Nile virus," The American Journal of Tropical Medicine and Hygiene, vol. 3, no. 1, pp. 19-50, 1954.

[27] J. T. Roehrig, D. Nash, B. Maldin et al., "Persistence of virusreactive serum immunoglobulin $\mathrm{M}$ antibody in confirmed West Nile virus encephalitis cases," Emerging Infectious Diseases, vol. 9, no. 3, pp. 376-379, 2003.

[28] H. E. Prince, L. H. Tobler, M. Lapé-Nixon, G. A. Foster, S. L. Stramer, and M. P. Busch, "Development and persistence of West Nile Virus-specific immunoglobulin M (IgM), IgA, and IgG in viremic blood donors," Journal of Clinical Microbiology, vol. 43, no. 9, pp. 4316-4320, 2005.

[29] D. S. Burke, A. Nisalak, and M. A. Ussery, "Kinetics in IgM and IgG responses to Japanese encephalitis virus in human serum and cerebrospinal fluid," Journal of Infectious Diseases, vol. 151, no. 6, pp. 1093-1099, 1985.

[30] M. Ndiva Mongoh, R. Hearne, N. W. Dyer, and M. L. Khaitsa, "The economic impact of West Nile virus infection in horses in the North Dakota equine industry in 2002," Tropical Animal Health and Production, vol. 40, no. 1, pp. 69-76, 2008.

[31] E. N. Ostlund, R. L. Crom, D. D. Pedersen, D. J. Johnson, W. O. Williams, and B. J. Schmitt, "Equine West Nile encephalitis, United States," Emerging Infectious Diseases, vol. 7, no. 4, pp. 665-669, 2001.

[32] B. S. Davis, G. J. J. Chang, B. Cropp et al., "West nile virus recombinant DNA vaccine protects mouse and horse from virus challenge and expresses in vitro a noninfectious recombinant antigen that can be used in enzyme-linked immunosorbent assays," Journal of Virology, vol. 75, no. 9, pp. 40404047, 2001.

[33] K. K. Seino, M. T. Long, E. P. J. Gibbs et al., "Comparative efficacies of three commercially available vaccines against
West Nile virus (WNV) in a short-duration challenge trial involving an equine WNV encephalitis model," Clinical and Vaccine Immunology, vol. 14, no. 11, pp. 1465-1471, 2007.

[34] G. P. Gard, I. D. Marshall, K. H. Walker, H. M. Acland, and W. G. Saren, "Association of Australian arboviruses with nervous disease in horses," Australian Veterinary Journal, vol. 53, no. 2, pp. 61-66, 1977.

[35] R. Badman, "Arbovirus infection in horses-Victoria 1984," Communicable Disease Intelligence, vol. 84 , no. 17, pp. 5-6, 1984.

[36] R. A. Hall, A. K. Broom, D. W. Smith, and J. S. Mackenzie, "The ecology and epidemiology of Kunjin virus," Current Topics in Microbiology and Immunology, vol. 267, pp. 253269, 2002.

[37] B. H. Kay, C. C. Pollitt, I. D. Fanning, and R. A. Hall, "The experimental infection of horses with Murray Valley encephalitis and Ross River viruses," Australian Veterinary Journal, vol. 64 , no. 2 , pp. 52-55, 1987.

[38] C. A. Reimann, E. B. Hayes, C. DiGuiseppi et al., "Epidemiology of neuroinvasive arboviral disease in the United States, 1999-2007," The American Journal of Tropical Medicine and Hygiene, vol. 79, no. 6, pp. 974-979, 2008.

[39] N. L. Marlenee, M. A. Loroño-Pino, B. J. Beaty et al., "Detection of antibodies to West Nile and Saint Louis encephalitis viruses in horses," Salud Publica de Mexico, vol. 46, no. 5, pp. 373-375, 2004.

[40] M. A. Loroño-Pino, B. J. Blitvich, J. A. Farfán-Ale et al., "Serologic evidence of West Nile virus infection in horses, Yucatan State, Mexico," Emerging Infectious Diseases, vol. 9, no. 7, pp. 857-859, 2003.

[41] J. A. Farfán-Ale, B. J. Blitvich, N. L. Marlenee et al., "Antibodies to West Nile virus in asymptomatic mammals, birds, and reptiles in the Yucatan Peninsula of Mexico," The American Journal of Tropical Medicine and Hygiene, vol. 74, no. 5, pp. 908-914, 2006.

[42] S. Mattar, N. Komar, G. Young, J. Alvarez, and M. Gonzalez, "Seroconversion for West Nile and St. Louis encephalitis viruses among sentinel horses in Colombia," Memorias do Instituto Oswaldo Cruz, vol. 106, no. 8, pp. 976-979, 2011.

[43] G. Savini, F. Monaco, C. Terregino et al., "Usutu virus in ITALY: an emergence or a silent infection?” Veterinary Microbiology, vol. 151, no. 3-4, pp. 264-274, 2011.

[44] F. Cavrini, P. Gaibani, G. Longo et al., "Usutu virus infection in a patient who underwent orthotropic liver transplantation, Italy, August-September 2009," Euro Surveillance, vol. 14, no. 50, 2009.

[45] M. Pecorari, G. Longo, W. Gennari et al., "First human case of Usutu virus neuroinvasive infection, Italy, August-September 2009," Euro Surveillance, vol. 14, no. 50, 2009.

[46] A. Papa, D. Karabaxoglou, and A. Kansouzidou, "Acute West Nile virus neuroinvasive infections: cross-reactivity with dengue virus and tick-borne encephalitis virus," Journal of Medical Virology, vol. 83, no. 10, pp. 1861-1865, 2011.

[47] J. P. Ledermann, M. A. Lorono-Pino, C. Ellis et al., "Evaluation of widely used diagnostic tests to detect West Nile virus infections in horses previously infected with St. Louis encephalitis virus or dengue virus type 2," Clinical and Vaccine Immunology, vol. 18, no. 4, pp. 580-587, 2011.

[48] K. L. Mansfield, D. L. Horton, N. Johnson et al., "Flavivirusinduced antibody cross-reactivity," Journal of General Virology, vol. 92, part 12, pp. 2821-2829, 2011.

[49] J. Hirota, H. Nishi, H. Matsuda, H. Tsunemitsu, and S. Shimizu, "Cross-reactivity of Japanese encephalitis virusvaccinated horse sera in serodiagnosis of West Nile Virus," 
Journal of Veterinary Medical Science, vol. 72, no. 3, pp. 369372, 2010.

[50] S. Mukhopadhyay, B. S. Kim, P. R. Chipman, M. G. Rossmann, and R. J. Kuhn, "Structure of West Nile virus," Science, vol. 302, no. 5643, p. 248, 2003.

[51] R. J. Kuhn, W. Zhang, M. G. Rossmann et al., "Structure of dengue virus: implications for flavivirus organization, maturation, and fusion," Cell, vol. 108, no. 5, pp. 717-725, 2002.

[52] G. Coia, M. D. Parker, G. Speight, M. E. Byrne, and E. G. Westaway, "Nucleotide and complete amino acid sequences of Kunjin virus: definitive gene order and characteristics of the virus-specified proteins," Journal of General Virology, vol. 69, no. 1, pp. 1-21, 1988.

[53] R. S. Lanciotti, J. T. Roehrig, V. Deubel et al., "Origin of the West Nile virus responsible for an outbreak of encephalitis in the Northeastern United States," Science, vol. 286, no. 5448, pp. 2333-2337, 1999.

[54] G. Wengler and G. Wengler, "Terminal sequences of the genome and replicative-form RNA of the flavivirus West Nile virus: absence of poly(A) and possible role in RNA replication," Virology, vol. 113, no. 2, pp. 544-555, 1981.

[55] C. M. Rice, E. M. Lenches, and S. R. Eddy, "Nucleotide sequence of yellow fever virus: implications for flavivirus gene expression and evolution," Science, vol. 229, no. 4715, pp. 726-733, 1985.

[56] R. A. Hall, A. K. Broom, A. C. Hartnett, M. J. Howard, and J. S. Mackenzie, "Immunodominant epitopes on the NS1 proteins of MVE and KUN viruses serve as targets for a blocking ELISA to detect virus-speciic antibodies in sentinel animal serum," Journal of Virological Methods, vol. 51, no. 2-3, pp. 201-210, 1995.

[57] S. J. Wong, V. L. Demarest, R. H. Boyle et al., "Detection of human anti-flavivirus antibodies with a West Nile Virus recombinant antigen microsphere immunoassay," Journal of Clinical Microbiology, vol. 42, no. 1, pp. 65-72, 2004.

[58] B. J. Blitvich, R. A. Bowen, N. L. Marlenee, R. A. Hall, M. L. Bunning, and B. J. Beaty, "Epitope-blocking enzymelinked immunosorbent assays for detection of West Nile virus antibodies in domestic mammals," Journal of Clinical Microbiology, vol. 41, no. 6, pp. 2676-2679, 2003.

[59] M. Throsby, C. Geuijen, J. Goudsmit et al., "Isolation and characterization of human monoclonal antibodies from individuals infected with West Nile Virus," Journal of Virology, vol. 80, no. 14, pp. 6982-6992, 2006.

[60] J. Hobson-Peters, P. Toye, M. D. Sánchez et al., "A glycosylated peptide in the West Nile virus envelope protein is immunogenic during equine infection," Journal of General Virology, vol. 89, part 12, pp. 3063-3072, 2008.

[61] J. Hobson-Peters, C. Arévalo, W. Y. Cheah et al., "Detection of antibodies to West Nile virus in horses, Costa Rica, 2004," Vector-Borne and Zoonotic Diseases, vol. 11, no. 8, pp. 10811084, 2011.

[62] Y. X. Setoh, J. Hobson-Peters, N. A. Prow, P. R. Young, and R. A. Hall, "Expression of recombinant West Nile virus prM protein fused to an affinity tag for use as a diagnostic antigen," Journal of Virological Methods, vol. 175, no. 1, pp. 20-27, 2011.

[63] S. J. Wong, R. H. Boyle, V. L. Demarest et al., "Immunoassay targeting nonstructural protein 5 to differentiate West Nile virus infection from dengue and St. Louis encephalitis virus infections and from flavivirus vaccination," Journal of Clinical Microbiology, vol. 41, no. 9, pp. 4217-4223, 2003.
[64] H. E. Prince, M. Lapé-Nixon, C. Yeh, L. H. Tobler, and M. P. Busch, "Persistence of antibodies to West Nile virus nonstructural protein 5," Journal of Clinical Virology, vol. 43, no. 1, pp. 102-106, 2008.

[65] M. A. Brinton, I. Kurane, A. Mathew et al., "Immune mediated and inherited defences against flaviviruses," Clinical and Diagnostic Virology, vol. 10, no. 2-3, pp. 129-139, 1998.

[66] J. T. Roehrig, "Antigenic structure of flavivirus proteins," Advances in Virus Research, vol. 59, pp. 141-175, 2003.

[67] T. C. Pierson and M. S. Diamond, "Molecular mechanisms of antibody-mediated neutralisation of flavivirus infection," Expert Reviews in Molecular Medicine, vol. 10, p. e12, 2008.

[68] F. A. Rey, F. X. Heinz, C. Mandl, C. Kunz, and S. C. Harrison, "The envelope glycoprotein from tick-borne encephalitis virus at $2 \AA$ resolution,” Nature, vol. 375, no. 6529, pp. 291298, 1995.

[69] G. E. Nybakken, C. A. Nelson, B. R. Chen, M. S. Diamond, and D. H. Fremont, "Crystal structure of the West Nile virus envelope glycoprotein," Journal of Virology, vol. 80, no. 23, pp. 11467-11474, 2006.

[70] S. L. Allison, J. Schalich, K. Stiasny, C. W. Mandl, and F. X. Heinz, "Mutational evidence for an internal fusion peptide in flavivirus envelope protein E," Journal of Virology, vol. 75, no. 9, pp. 4268-4275, 2001.

[71] G. E. Nybakken, T. Oliphant, S. Johnson, S. Burke, M. S. Diamond, and D. H. Fremont, "Structural basis of West Nile virus neutralization by a therapeutic antibody," Nature, vol. 437, no. 7059, pp. 764-769, 2005.

[72] J. J. H. Chu, R. Rajamanonmani, J. Li, R. Bhuvananakantham, J. Lescar, and M. L. Ng, "Inhibition of West Nile virus entry by using a recombinant domain III from the envelope glycoprotein," Journal of General Virology, vol. 86, part 2, pp. 405412, 2005.

[73] T. Oliphant, G. E. Nybakken, M. Engle et al., "Antibody recognition and neutralization determinants on domains I and II of West Nile virus envelope protein," Journal of Virology, vol. 80, no. 24, pp. 12149-12159, 2006.

[74] M. D. Sánchez, T. C. Pierson, M. M. DeGrace et al., "The neutralizing antibody response against West Nile virus in naturally infected horses," Virology, vol. 359, no. 2, pp. 336-348, 2007.

[75] M. D. Sánchez, T. C. Pierson, D. McAllister et al., "Characterization of neutralizing antibodies to West Nile virus," Virology, vol. 336, no. 1, pp. 70-82, 2005.

[76] D. W. C. Beasley and A. D. T. Barrett, "Identification of neutralizing epitopes within structural domain III of the West Nile virus envelope protein," Journal of Virology, vol. 76, no. 24, pp. 13097-13100, 2002.

[77] K. S. Choi, J. J. Nah, Y. J. Ko, Y. J. Kim, and Y. S. Joo, "The DE loop of the domain III of the envelope protein appears to be associated with West Nile virus neutralization," Virus Research, vol. 123, no. 2, pp. 216-218, 2007.

[78] K. Stiasny, S. Kiermayr, H. Holzmann, and F. X. Heinz, "Cryptic properties of a cluster of dominant flavivirus crossreactive antigenic sites," Journal of Virology, vol. 80, no. 19, pp. 9557-9568, 2006.

[79] W. D. Crill, N. B. Trainor, and G. J. J. Chang, "A detailed mutagenesis study of flavivirus cross-reactive epitopes using west Nile virus-like particles," Journal of General Virology, vol. 88, part 4, pp. 1169-1174, 2007.

[80] Y. Zhang, J. Corver, P. R. Chipman et al., "Structures of immature flavivirus particles," The EMBO Journal, vol. 22, no. 11, pp. 2604-2613, 2003. 
[81] Y. Zhang, B. Kaufmann, P. R. Chipman, R. J. Kuhn, and M. G. Rossmann, "Structure of immature West Nile virus," Journal of Virology, vol. 81, no. 11, pp. 6141-6145, 2007.

[82] C. W. Davis, L. M. Mattei, H. Y. Nguyen, C. AnsarahSobrinho, R. W. Doms, and T. C. Pierson, "The location of asparagine-linked glycans on west nile virions controls their interactions with CD209 (dendritic cell-specific ICAM-3 grabbing nonintegrin)," Journal of Biological Chemistry, vol. 281, no. 48, pp. 37183-37194, 2006.

[83] V. B. Randolph, G. Winkler, and V. Stollar, "Acidotropic amines inhibit proteolytic processing of flavivirus prM protein," Virology, vol. 174, no. 2, pp. 450-458, 1990.

[84] K. Stadler, S. L. Allison, J. Schalich, and F. X. Heinz, "Proteolytic activation of tick-borne encephalitis virus by furin," Journal of Virology, vol. 71, no. 11, pp. 8475-8481, 1997.

[85] S. L. Allison, J. Schalich, K. Stiasny, C. W. Mandl, C. Kunz, and F. X. Heinz, "Oligomeric rearrangement of tick-borne encephalitis virus envelope proteins induced by an acidic pH," Journal of Virology, vol. 69, no. 2, pp. 695-700, 1995.

[86] S. Elshuber, S. L. Allison, F. X. Heinz, and C. W. Mandl, "Cleavage of protein prM is necessary for infection of BHK21 cells by tick-borne encephalitis virus," Journal of General Virology, vol. 84, part 1, pp. 183-191, 2003.

[87] L. Li, S. M. Lok, I. M. Yu et al., "The flavivirus precursor membrane-envelope protein complex: structure and maturation," Science, vol. 319, no. 5871, pp. 1830-1834, 2008.

[88] F. Guirakhoo, R. A. Bolin, and J. T. Roehrig, "The Murray Valley encephalitis virus prM protein confers acid resistance to virus particles and alters the expression of epitopes within the R2 domain of E glycoprotein," Virology, vol. 191, no. 2, pp. 921-931, 1992.

[89] M. J. Cardosa, S. M. Wang, M. S. Sum, and P. H. Tio, “Antibodies against prM protein distinguish between previous infection with dengue and Japanese encephalitis viruses," BMC Microbiology, vol. 2, article 9, 2002.

[90] M. Bray and C. J. Lai, "Dengue virus premembrane and membrane proteins elicit a protective immune response," Virology, vol. 185, no. 1, pp. 505-508, 1991.

[91] L. C. Iacono-Connors, J. F. Smith, T. G. Ksiazek, C. L. Kelley, and C. S. Schmaljohn, "Characterization of Langat virus antigenic determinants defined by monoclonal antibodies to $\mathrm{E}, \mathrm{NS} 1$ and preM and identification of a protective, nonneutralizing preM-specific monoclonal antibody," Virus Research, vol. 43, no. 2, pp. 125-136, 1996.

[92] A. K. I. Falconar, "Identification of an epitope on the dengue virus membrane $(\mathrm{M})$ protein defined by cross-protective monoclonal antibodies: design of an improved epitope sequence based on common determinants present in both envelope (E and M) proteins," Archives of Virology, vol. 144, no. 12, pp. 2313-2330, 1999.

[93] S. Vázquez, M. G. Guzmán, G. Guillen et al., "Immune response to synthetic peptides of dengue prM protein," Vaccine, vol. 20, no. 13-14, pp. 1823-1830, 2002.

[94] L. F. Oceguera III, P. J. Patiris, R. E. Chiles, M. P. Busch, L. H. Tobler, and C. V. Hanson, "Flavivirus serology by western blot analysis," The American Journal of Tropical Medicine and Hygiene, vol. 77, no. 1, pp. 159-163, 2007.

[95] B. J. Blitvich, D. Scanlon, B. J. Shiell, J. S. Mackenzie, K. Pham, and R. A. Hall, "Determination of the intramolecular disulfide bond arrangement and biochemical identification of the glycosylation sites of the nonstructural protein NS1 of Murray Valley encephalitis virus," Journal of General Virology, vol. 82, part 9, pp. 2251-2256, 2001.
[96] T. P. Wallis, C. Y. Huang, S. B. Nimkar, P. R. Young, and J. J. Gorman, "Determination of the disulfide bond arrangement of dengue virus NS1 protein," Journal of Biological Chemistry, vol. 279, no. 20, pp. 20729-20741, 2004.

[97] I. Gutsche, F. Coulibaly, J. E. Voss et al., "Secreted dengue virus nonstructural protein NS1 is an atypical barrel-shaped high-density lipoprotein," Proceedings of the National Academy of Sciences of the United States of America, vol. 108, no. 19, pp. 8003-8008, 2011.

[98] D. A. Muller, M. J. Landsberg, C. Bletchly et al., "Structure of the dengue virus glycoprotein NS1 by electron microscopy and single particle analysis," Journal of General Virology, vol. 93, part 4, pp. 771-779, 2012.

[99] A. A. Khromykh, P. L. Sedlak, K. J. Guyatt, R. A. Hall, and E. G. Westaway, "Efficient trans-complementation of the flavivirus Kunjin NS5 protein but not of the NS1 protein requires its coexpression with other components of the viral replicase," Journal of Virology, vol. 73, no. 12, pp. 10272-10280, 1999.

[100] J. M. Mackenzie, M. K. Jones, and P. R. Young, "Immunolocalization of the Dengue virus nonstructural glycoprotein NS1 suggests a role in viral RNA replication," Virology, vol. 220, no. 1, pp. 232-240, 1996.

[101] B. D. Lindenbach and C. M. Rice, "Molecular biology of flaviviruses," Advances in Virus Research, vol. 59, pp. 23-61, 2003.

[102] B. D. Lindenbach and C. M. Rice, "Trans-complementation of yellow fever virus NS1 reveals a role in early RNA replication," Journal of Virology, vol. 71, no. 12, pp. 9608-9617, 1997.

[103] K. M. Chung, M. K. Liszewski, G. Nybakken et al., "West Nile virus nonstructural protein NS1 inhibits complement activation by binding the regulatory protein factor $\mathrm{H}$," Proceedings of the National Academy of Sciences of the United States of America, vol. 103, no. 50, pp. 19111-19116, 2006.

[104] J. Macdonald, J. Tonry, R. A. Hall et al., "NS1 protein secretion during the acute phase of West Nile virus infection," Journal of Virology, vol. 79, no. 22, pp. 13924-13933, 2005.

[105] P. R. Young, P. A. Hilditch, C. Bletchly, and W. Halloran, "An antigen capture enzyme-linked immunosorbent assay reveals high levels of the dengue virus protein NS1 in the sera of infected patients," Journal of Clinical Microbiology, vol. 38, no. 3, pp. 1053-1057, 2000.

[106] S. Alcon, A. Talarmin, M. Debruyne, A. Falconar, V. Deubel, and M. Flamand, "Enzyme-linked immunosorbent assay specific to dengue virus type 1 nonstructural protein NS1 reveals circulation of the antigen in the blood during the acute phase of disease in patients experiencing primary or secondary infections," Journal of Clinical Microbiology, vol. 40, no. 2, pp. 376-381, 2002.

[107] D. H. Libraty, P. R. Young, D. Pickering et al., "High circulating levels of the dengue virus nonstructural protein NS1 early in dengue illness correlate with the development of dengue hemorrhagic fever," Journal of Infectious Diseases, vol. 186, no. 8, pp. 1165-1168, 2002.

[108] W. A. Falkler Jr., A. R. Diwan, and S. B. Halstead, "Human antibody to dengue soluble complement fixing (SCF) antigens," Journal of Immunology, vol. 111, no. 6, pp. 1804-1809, 1973.

[109] G. Kuno, A. V. Vorndam, D. J. Gubler, and I. Gomez, "Study of anti-dengue NS1 antibody by Western blot," Journal of Medical Virology, vol. 32, no. 2, pp. 102-108, 1990.

[110] K. Valdes, M. Alvarez, M. Pupo, S. Vazquez, R. Rodriguez, and M. G. Guzman, "Human dengue antibodies against 
structural and nonstructural proteins," Clinical and Diagnostic Laboratory Immunology, vol. 7, no. 5, pp. 856-857, 2000.

[111] K. M. Chung, G. E. Nybakken, B. S. Thompson et al., "Antibodies against West Nile virus nonstructural protein NS1 prevent lethal infection through Fc $\gamma$ receptor-dependent and -independent mechanisms," Journal of Virology, vol. 80, no. 3, pp. 1340-1351, 2006.

[112] S. M. Costa, A. S. Azevedo, M. V. Paes, F. S. Sarges, M. S. Freire, and A. M. B. Alves, "DNA vaccines against dengue virus based on the ns1 gene: the influence of different signal sequences on the protein expression and its correlation to the immune response elicited in mice," Virology, vol. 358, no. 2, pp. 413-423, 2007.

[113] C. W. Lin, K. T. Liu, H. D. Huang, and W. J. Chen, "Protective immunity of E. coli-synthesized NS1 protein of Japanese encephalitis virus," Biotechnology Letters, vol. 30, no. 2, pp. 205214, 2008.

[114] V. Deubel, V. Mouly, and J. J. Salaun, "Comparison of the enzyme-linked immunosorbent assay (ELISA) with standard tests used to detect yellow fever virus antibodies," The American Journal of Tropical Medicine and Hygiene, vol. 32, no. 3, pp. 565-568, 1983.

[115] P. Y. Shu, L. K. Chen, S. F. Chang et al., "Potential application of nonstructural protein NS1 serotype-specific immunoglobulin $G$ enzyme-linked immunosorbent assay in the seroepidemiologic study of dengue virus infection: correlation of results with those of the plaque reduction neutralization test," Journal of Clinical Microbiology, vol. 40, no. 5, pp. 1840-1844, 2002.

[116] Y. Kitai, M. Shoda, T. Kondo, and E. Konishi, "Epitopeblocking enzyme-linked immunosorbent assay to differentiate West Nile virus from Japanese encephalitis virus infections in equine sera," Clinical and Vaccine Immunology, vol. 14, no. 8, pp. 1024-1031, 2007.

[117] R. A. Hall, G. W. Burgess, and B. H. Kay, “Type-specific monoclonal antibodies produced to proteins of Murray Valley encephalitis virus," Immunology and Cell Biology, vol. 66, part 1, pp. 51-56, 1988.

[118] R. A. Hall, B. H. Kay, G. W. Burgess, P. Clancy, and I. D. Fanning, "Epitope analysis of the envelope and non-structural glycoproteins of Murray Valley encephalitis virus," Journal of General Virology, vol. 71, part 12, no. 12, pp. 2923 2930, 1990.

[119] E. A. Henchal, L. S. Henchal, and J. J. Schlesinger, "Synergistic interactions of anti-NS1 monoclonal antibodies protect passively immunized mice from lethal challenge with dengue 2 virus," Journal of General Virology, vol. 69, part 8, pp. 21012107, 1988.

[120] D. C. Clark, M. Lobigs, E. Lee et al., "In situ reactions of monoclonal antibodies with a viable mutant of murray valley encephalitis virus reveal an absence of dimeric NS1 protein," Journal of General Virology, vol. 88, part 4, pp. 1175-1183, 2007.

[121] K. M. Chung and M. S. Diamond, "Defining the levels of secreted non-structural protein NS1 after West Nile virus infection in cell culture and mice," Journal of Medical Virology, vol. 80, no. 3, pp. 547-556, 2008.

[122] H. S. Lindsey, C. H. Calisher, and J. H. Mathews, "Serum dilution neutralization test for California group virus identification and serology," Journal of Clinical Microbiology, vol. 4, no. 6, pp. 503-510, 1976.

[123] B. J. Beaty, C. H. Calisher, and R. E. Shope, "Arboviruses," in Diagnostic Procedures for Viral and Rickettsial Diseases, N.
J. Schmidt and R. W. Emmons, Eds., pp. 189-212, American Public Health Association, Washington DC, USA, 1995.

[124] D. H. Clarke and J. Casals, "Techniques for hemagglutination and hemagglutination-inhibition with arthropod-borne viruses," The American Journal of Tropical Medicine and Hygiene, vol. 7, no. 5, pp. 561-573, 1958.

[125] A. Hiscox, C. H. Winter, P. Vongphrachanh et al., "Serological investigations of flavivirus prevalence in Khammouane Province, Lao People's Democratic Republic, 2007-2008," The American Journal of Tropical Medicine and Hygiene, vol. 83, no. 5, pp. 1166-1169, 2010.

[126] A. Yamanaka, K. C. Mulyatno, H. Susilowati et al., "Prevalence of antibodies to japanese encephalitis virus among pigs in Bali and East Java, Indonesia, 2008," Japanese Journal of Infectious Diseases, vol. 63, no. 1, pp. 58-60, 2010.

[127] T. P. Endy and A. Nisalak, "Japanese encephalitis virus: ecology and epidemiology," in Japanese Encephalitis and West Nile Viruses, J. M. Mackenzie, A. D. Barrett, and V. Deubel, Eds., pp. 11-48, Springer, Berlin, Germany, 2002.

[128] P. Koraka, H. Zeller, M. Niedrig, A. D. M. E. Osterhaus, and J. Groen, "Reactivity of serum samples from patients with a flavivirus infection measured by immunofluorescence assay and ELISA," Microbes and Infection, vol. 4, no. 12, pp. 12091215, 2002.

[129] M. Niedrig, O. Donoso Mantke, D. Altmann, and H. Zeller, "First international diagnostic accuracy study for the serological detection of West Nile virus infection," BMC Infectious Diseases, vol. 7, article 72, 2007.

[130] M. Niedrig, K. Sonnenberg, K. Steinhagen, and J. T. Paweska, "Comparison of ELISA and immunoassays for measurement of IgG and IgM antibody to West Nile virus in human sera against virus neutralisation," Journal of Virological Methods, vol. 139, no. 1, pp. 103-105, 2007.

[131] "Focus diagnostics product brochure," http://www.focusdx .com/pdfs/brochures/DXFWVO411_West_Nile_Virus.pdf.

[132] West Nile Virus IgM Capture DxSelect Product Insert PI.EL0300M Rev. L.

[133] A. R. Sambol, S. H. Hinrichs, W. R. Hogrefe, and B. K. Schweitzer, "Performance of a commercial immunoglobulin $\mathrm{M}$ antibody capture assay using analyte-specific reagents to screen for interfering factors during a West Nile virus epidemic season in Nebraska," Clinical and Vaccine Immunology, vol. 14, no. 1, pp. 87-89, 2007.

[134] A. J. Johnson, A. J. Noga, O. Kosoy, R. S. Lanciotti, A. A. Johnson, and B. J. Biggerstaff, "Duplex microsphere-based immunoassay for detection of anti-West Nile virus and antiSt. Louis encephalitis virus immunoglobulin M antibodies," Clinical and Diagnostic Laboratory Immunology, vol. 12, no. 5, pp. 566-574, 2005.

[135] A. J. Johnson, R. C. Cheshier, G. Cosentino et al., "Valida-tion of a microsphere-based immunoassay for detection of antiwest nile virus and anti-St. Louis encephalitis virus immunoglobulin M antibodies," Clinical and Vaccine Immunology, vol. 14, no. 9, pp. 1084-1093, 2007.

[136] J. A. Roberson, W. D. Crill, and G. J. J. Chang, "Differentiation of West Nile and St. Louis encephalitis virus infections by use of noninfectious virus-like particles with reduced crossreactivity," Journal of Clinical Microbiology, vol. 45, no. 10, pp. 3167-3174, 2007.

[137] D. W. C. Beasley, M. R. Holbrook, A. P. A. Travassos Da Rosa et al., "Use of a recombinant envelope protein subunit antigen for specific serological diagnosis of West Nile virus infection," Journal of Clinical Microbiology, vol. 42, no. 6, pp. 2759-2765, 2004. 
[138] S. Herrmann, B. Leshem, L. Lobel et al., "T7 phage display of Ep15 peptide for the detection of WNV IgG," Journal of Virological Methods, vol. 141, no. 2, pp. 133-140, 2007.

[139] R.-H. Hua, N.-S. Chen, C.-F. Qin et al., "Identification and characterization of a virus-specific continuous B-cell epitope on the PrM/M protein of Japanese encephalitis Virus: potential application in the detection of antibodies to distinguish Japanese encephalitis Virus infection from West Nile Virus and Dengue Virus infections," Virology Journal, vol. 7, article 249, 2010.

[140] G. Dauphin and S. Zientara, "West Nile virus: recent trends in diagnosis and vaccine development," Vaccine, vol. 25, no. 30, pp. 5563-5576, 2007.

[141] A. J. Johnson, D. A. Martin, N. Karabatsos, and J. T. Roehrig, "Detection of anti-arboviral immunoglobulin G by using a monoclonal antibody-based capture enzyme-linked immunosorbent assay," Journal of Clinical Microbiology, vol. 38 , no. 5, pp. 1827-1831, 2000.

[142] D. A. Martin, D. A. Muth, T. Brown, A. J. Johnson, N. Karabatsos, and J. T. Roehrig, "Standardization of immunoglobulin M capture enzyme-linked immunosorbent assays for routine diagnosis of arboviral infections," Journal of Clinical Microbiology, vol. 38, no. 5, pp. 1823-1826, 2000.

[143] M. T. Long, W. Jeter, J. Hernandez et al., "Diagnostic performance of the equine IgM capture ELISA for serodiagnosis of West Nile virus infection," Journal of Veterinary Internal Medicine, vol. 20, no. 3, pp. 608-613, 2006.

[144] M. L. Rawlins, E. M. Swenson, H. R. Hill, and C. M. Litwin, "Evaluation of an enzyme immunoassay for detection of immunoglobulin $\mathrm{M}$ antibodies to West Nile virus and the importance of background subtraction in detecting nonspecific reactivity," Clinical and Vaccine Immunology, vol. 14, no. 6, pp. 665-668, 2007.

[145] P. N. Levett, K. Sonnenberg, F. Sidaway et al., "Use of immunoglobulin $G$ avidity assays for differentiation of primary from previous infections with West Nile virus," Journal of Clinical Microbiology, vol. 43, no. 12, pp. 5873-5875, 2005.

[146] D. A. Martin, A. Noga, O. Kosoy, A. J. Johnson, L. R. Petersen, and R. S. Lanciotti, "Evaluation of a diagnostic algorithm using immunoglobulin $\mathrm{M}$ enzyme-linked immunosorbent assay to differentiate human West Nile virus and St. Louis encephalitis virus infections during the 2002 West Nile virus epidemic in the United States," Clinical and Diagnostic Laboratory Immunology, vol. 11, no. 6, pp. 1130-1133, 2004.

[147] W. Zhang, J. Wu, Y. Li, F. Li, and H. Njoo, "Rapid and accurate in vitro assays for detection of West Nile Virus in blood and tissues," Transfusion Medicine Reviews, vol. 23, no. 2, pp. 146-154, 2009.

[148] K. B. Janusz, J. A. Lehman, A. J. Panella, M. Fischer, and E. Staples, "Laboratory testing practices for west nile virus in the United States," Vector-Borne and Zoonotic Diseases, vol. 11, no. 5, pp. 597-599, 2011.

[149] E. Sotelo, F. Llorente, B. Rebollo et al., "Development and evaluation of a new epitope-blocking ELISA for universal detection of antibodies to West Nile virus," Journal of Virological Methods, vol. 174, no. 1-2, pp. 35-41, 2011.

[150] M. A. Loroño-Pino, J. A. Farfan-Ale, B. J. Blitvich, J. L. Beebe, R. G. Jarman, and B. J. Beaty, "Evaluation of an epitope-blocking enzyme-linked immunosorbent assay for the diagnosis of west nile virus infections in humans," Clinical and Vaccine Immunology, vol. 16, no. 5, pp. 749-755, 2009.

[151] B. J. Blitvich, I. Fernandez-Salas, J. F. Contreras-Cordero et al., "Serologic evidence of West Nile virus infection in horses,
Coahuila State, Mexico," Emerging Infectious Diseases, vol. 9, no. 7, pp. 853-856, 2003.

[152] B. J. Blitvich, N. L. Marlenee, R. A. Hall et al., "Epitopeblocking enzyme-linked immunosorbent assays for the detection of serum antibodies to West Nile virus in multiple avian species," Journal of Clinical Microbiology, vol. 41, no. 3, pp. 1041-1047, 2003.

[153] T. Lefrançois, B. J. Blitvich, J. Pradel, S. Molia, N. Vachiéry, and D. Martinez, "West Nile virus in Guadeloupe: introduction, spread, and decrease in circulation level: 2002-2005," Annals of the New York Academy of Sciences, vol. 1081, pp. 206-215, 2006.

[154] T. Lefrançois, B. J. Blitvich, J. Pradel et al., "West Nile virus Surveillance, Guadeloupe, 2003-2004," Emerging Infectious Diseases, vol. 11, no. 7, pp. 1100-1103, 2005.

[155] O. Cabre, M. Grandadam, J. L. Marié et al., "West Nile virus in horses, sub-Saharan Africa," Emerging Infectious Diseases, vol. 12, no. 12, pp. 1958-1960, 2006.

[156] M. Taketa-Graham, J. L. Powell Pereira, E. Baylis et al., "High throughput quantitative colorimetric microneutralization assay for the confirmation and differentiation of west nile virus and St. Louis encephalitis virus," The American Journal of Tropical Medicine and Hygiene, vol. 82, no. 3, pp. 501-504, 2010.

[157] N. A. Shaikh, J. Ge, Y. X. Zhao, P. Walker, and M. Drebot, "Development of a novel, rapid, and sensitive immunochromatographic strip assay specific for West Nile virus (WNV) IgM and testing of its diagnostic accuracy in patients suspected of WNV infection," Clinical Chemistry, vol. 53, no. 11, pp. 2031-2034, 2007.

[158] P. Y. Shi and S. J. Wong, "Serologic diagnosis of West Nile virus infection," Expert Review of Molecular Diagnostics, vol. 3, no. 6, pp. 733-741, 2003.

[159] U. B.R. Balasuriya, P.-Y. Shi, S. J. Wong et al., "Detection of antibodies to West Nile virus in equine sera using microsphere immunoassay," Journal of Veterinary Diagnostic Investigation, vol. 18, no. 4, pp. 392-395, 2006.

[160] F. S. R. R. Teles, "Biosensors and rapid diagnostic tests on the frontier between analytical and clinical chemistry for biomolecular diagnosis of dengue disease: a review," Analytica Chimica Acta, vol. 687, no. 1, pp. 28-42, 2011.

[161] Y. F. Lee, K. Y. Lien, H. Y. Lei, and G. B. Lee, "An integrated microfluidic system for rapid diagnosis of dengue virus infection," Biosensors and Bioelectronics, vol. 25, no. 4, pp. 745$752,2009$.

[162] R. E. Ionescu, S. Cosnier, S. Herrmann, and R. S. Marks, "Amperometric immunosensor for the detection of antiWest Nile virus IgG," Analytical Chemistry, vol. 79, no. 22, pp. 8662-8668, 2007.

[163] J. Neng, M. H. Harpster, H. Zhang, J. O. Mecham, W. C. Wilson, and P. A. Johnson, "A versatile SERS-based immunoassay for immunoglobulin detection using antigen-coated gold nanoparticles and malachite green-conjugated protein A/G," Biosensors and Bioelectronics, vol. 26, no. 3, pp. 10091015, 2010.

[164] C. J. Hillyard, D. B. Rylatt, P. O. Bundesen, and B. E. Kemp, "Disease diagnosis in two minutes," Today's Life Science, vol. 3, pp. 52-60, 1991.

[165] K. M. Wilson, M. Gerometta, D. B. Rylatt et al., "Rapid whole blood assay for HIV-1 seropositivity using an Fab-peptide conjugate," Journal of Immunological Methods, vol. 138, no. 1, pp. 111-119, 1991.

[166] B. E. Kemp, D. B. Rylatt, P. G. Bundesen et al., "Autologous red cell agglutination assay for HIV-1 antibodies: simplified 
test with whole blood," Science, vol. 241, no. 4871, pp. $1352-$ 1354, 1988.

[167] D. B. Rylatt, B. E. Kemp, P. G. Bundesen et al., "A rapid wholeblood immunoassay system," Medical Journal of Australia, vol. 152, no. 2, pp. 75-77, 1990.

[168] A. Gupta and V. K. Chaudhary, "Whole-blood agglutination assay for on-site detection of human immunodeficiency virus infection," Journal of Clinical Microbiology, vol. 41, no. 7, pp. 2814-2821, 2003.

[169] Y. P. Chen, Y. Y. Qiao, X. H. Zhao, H. S. Chen, Y. Wang, and Z. Wang, "Rapid detection of hepatitis B virus surface antigen by an agglutination assay mediated by a bispecific diabody against both human erythrocytes and hepatitis B virus surface antigen," Clinical and Vaccine Immunology, vol. 14, no. 6, pp. 720-725, 2007.

[170] G. Coia, P. J. Hudson, and G. G. Lilley, "Construction of recombinant extended single-chain antibody peptide conjugates for use in the diagnosis of HIV-1 and HIV-2," Journal of Immunological Methods, vol. 192, no. 1-2, pp. 13-23, 1996.

[171] G. G. Lilley, O. Dolezal, C. J. Hillyard, C. Bernard, and P. J. Hudson, "Recombinant single-chain antibody peptide conjugates expressed in Escherichia coli for the rapid diagnosis of HIV," Journal of Immunological Methods, vol. 171, no. 2, pp. 211-226, 1994.

[172] A. Gupta, S. Gupta, and V. K. Chaudhary, "Recombinant fusion proteins for haemagglutination-based rapid detection of antibodies to HIV in whole blood," Journal of Immunological Methods, vol. 256, no. 1-2, pp. 121-140, 2001.

[173] A. Gupta and V. K. Chaudhary, "Bifunctional recombinant fusion proteins for rapid detection of antibodies to both HIV1 and HIV-2 in whole blood," BMC Biotechnology, vol. 6, article 39, 2006.

[174] A. Gupta and V. K. Chaudhary, "Expression, purification, and characterization of an anti-RBCFab-p24 fusion protein for hemagglutination-based rapid detection of antibodies to HIV in whole blood," Protein Expression and Purification, vol. 26, no. 1, pp. 162-170, 2002.

[175] J. Hobson-Peters, J. Shan, R. A. Hall, and P. Toye, "Mammalian expression of functional autologous red cell agglutination reagents for use in diagnostic assays," Journal of Virological Methods, vol. 168, no. 1-2, pp. 177-190, 2010.

[176] H. E. Prince and W. R. Hogrefe, "Assays for detecting West Nile Virus antibodies in human serum, plasma, and cerebrospinal fluid," Clinical and Applied Immunology Reviews, vol. 5, no. 1, pp. 45-63, 2005.

[177] T. R. Kline, M. K. Runyon, M. Pothiawala, and R. F. Ismagilov, "ABO, D blood typing and subtyping using plugbased microfluidics," Analytical Chemistry, vol. 80, no. 16, pp. 6190-6197, 2008. 

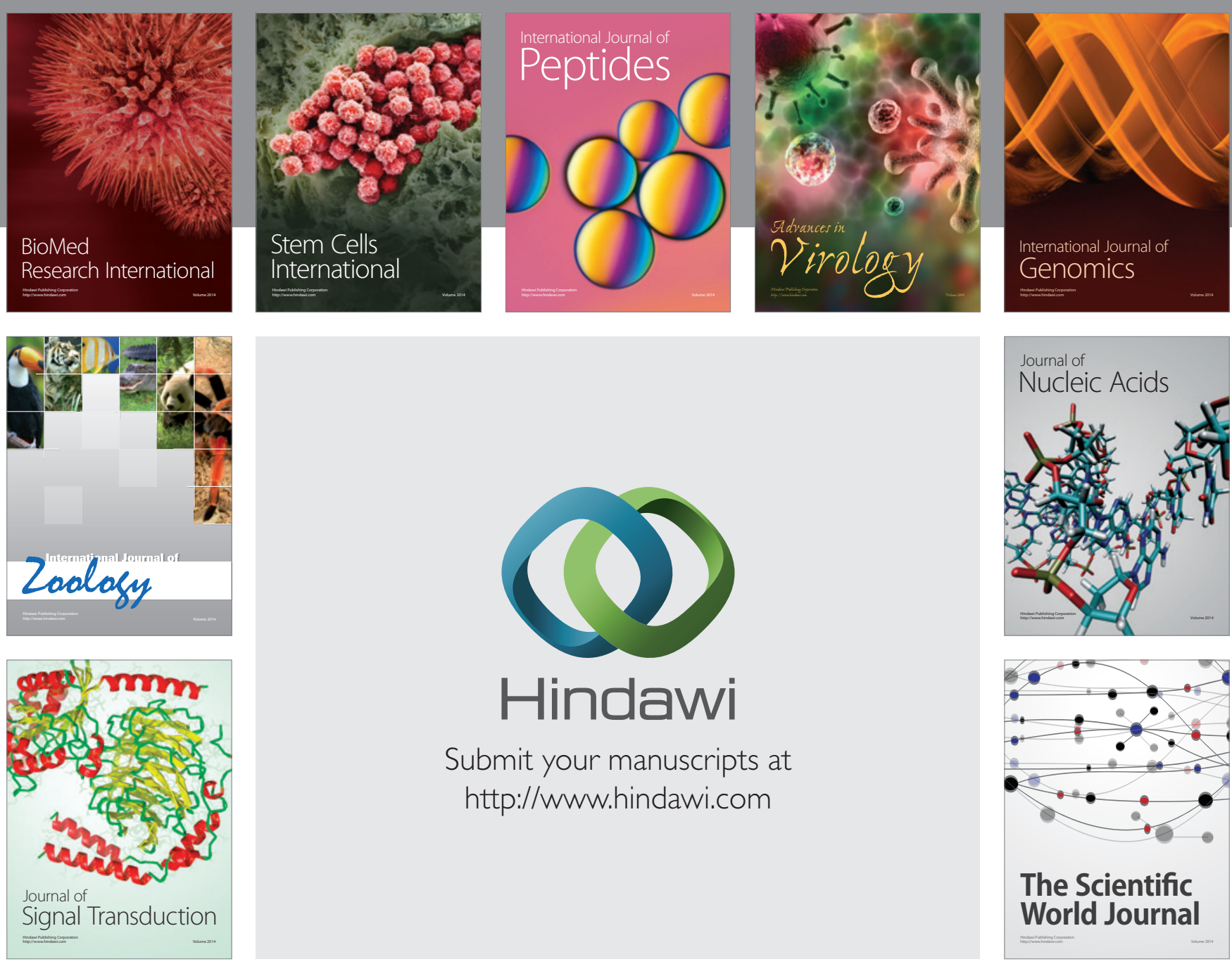

Submit your manuscripts at

http://www.hindawi.com
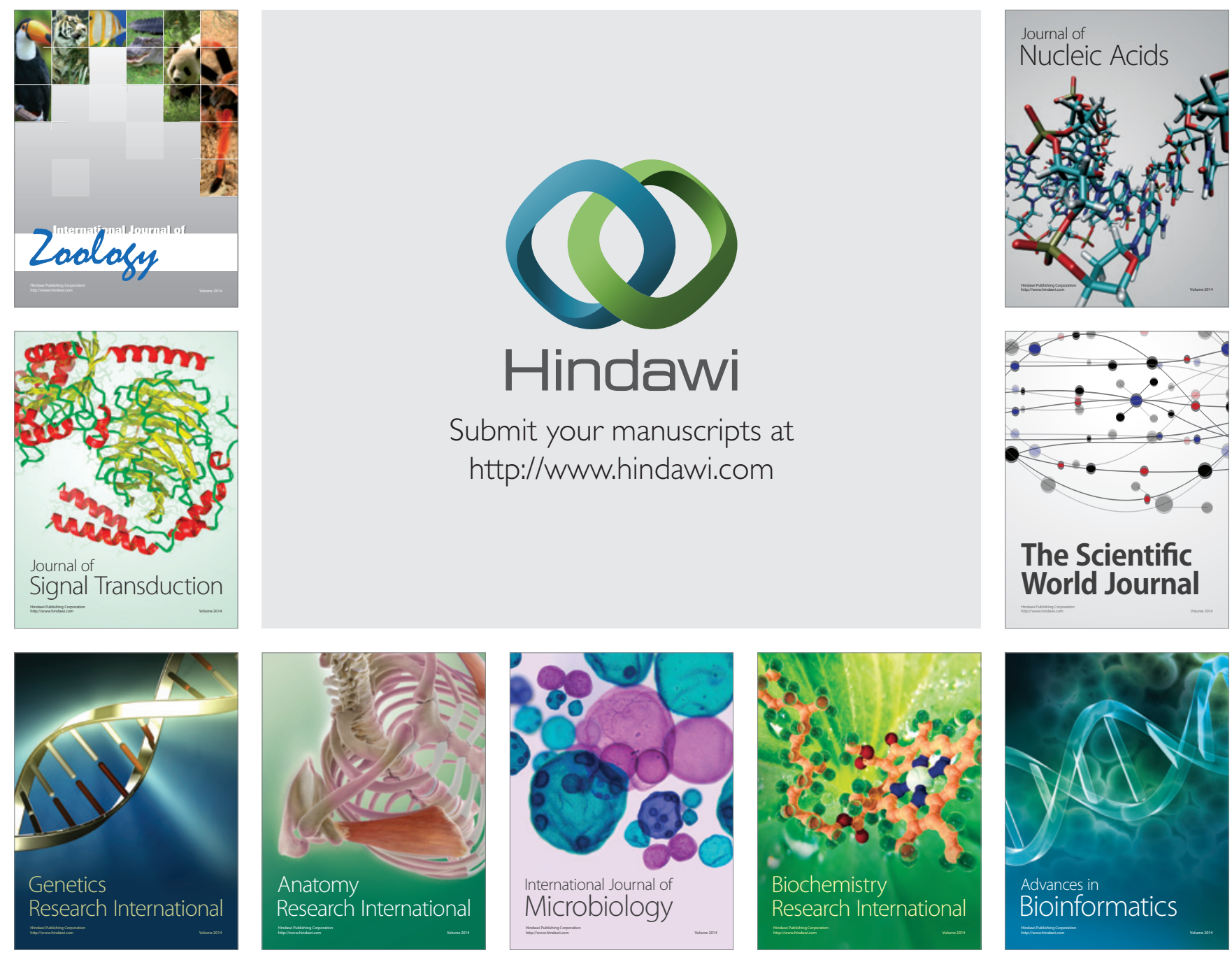

The Scientific World Journal
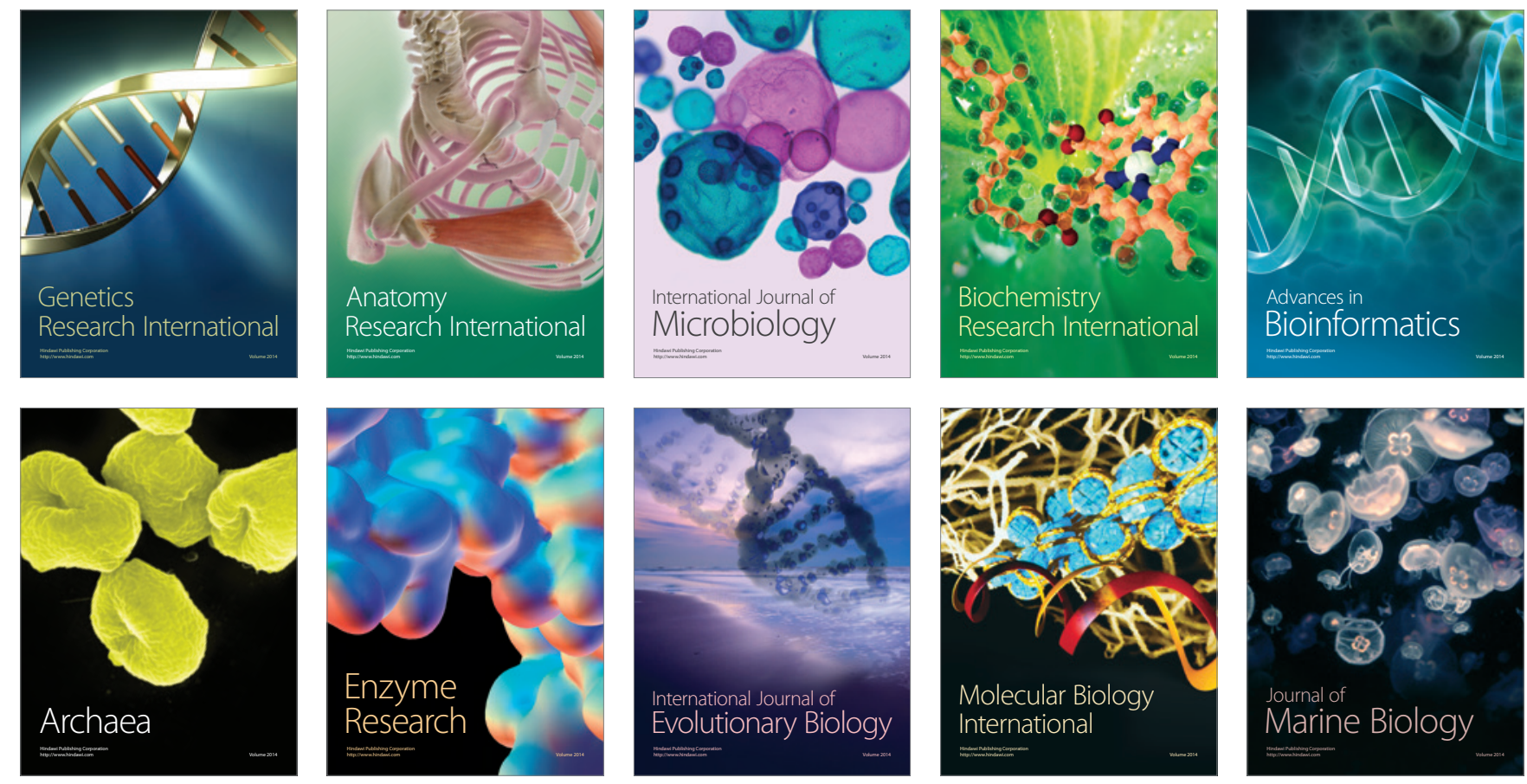